\title{
Acetylome and phosphoproteome modifications in imatinib resistant chronic myeloid leukaemia cells treated with valproic acid
}

\author{
Francesca Buchi ${ }^{a}$, Roberta Pastorelli ${ }^{b}$, Germano Ferrari ${ }^{a}$, Elena Spinelli ${ }^{a}$, Antonella Gozzini $^{a}$, \\ Francesca Sassolini ${ }^{a}$, Alberto Bosi ${ }^{a}$, Donatella Tombaccini ${ }^{b}$, Valeria Santini ${ }^{a}, *$ \\ a Functional Unit of Haematology, University of Florence, Florence, Italy \\ ${ }^{\mathrm{b}}$ Department of Experimental Pathology and Oncology, University of Florence, Florence, Italy
}

\section{A R T I C L E I N F O}

Article history:

Received 2 September 2010

Received in revised form 10 January 2011

Accepted 29 January 2011

Available online 5 March 2011

Keywords:

CML BCR/ABL

Proteomics

Imatinib resistance

Valproic acid

Protein phosphorylation

Protein acetylation

\begin{abstract}
A B S T R A C T
Chronic myeloid leukaemia has a specific therapy: BCR/ABL inhibitor imatinib. Resistance due to BCR/ABL dependent and independent mechanisms is partially reversible by histone deacetylase inhibitors. We analysed by 2D-electrophoresis and anti-pan-acetylated and anti-phosphotyrosine immunoblots, followed by spot-matching and MALDI-TOF mass spectrometry, which proteome modifications would parallel restoration of sensitivity to imatinib by valproic acid (VPA). VPA plus imatinib significantly increased acetylation of HSP90 and hnRNP L and decreased phosphorylation of HSPs and hnRNPs in imatinib resistant cells. VPA was able to modify profoundly acetylome and phosphoproteome of CML cells, while reverting resistance to imatinib.
\end{abstract}

(c) 2011 Elsevier Ltd. All rights reserved.

\section{Introduction}

Imatinib is an extremely effective therapy for chronic phase CML BCR/ABL positive, but patients may develop resistance, caused most frequently by point mutations within the kinase domain of $\mathrm{BCR}-\mathrm{ABL}$, or less often by amplification of the $B C R / A B L$ genomic locus [1]. Mechanisms independent of BCR/ABL activity are also supposed to cause resistance. Novel ABL kinase inhibitors or dual SRC/ABL kinase inhibitors with higher potency against native and imatinib-resistant mutants of BCR/ABL have substantial clinical utility, but at least one mutation located in the p-loop of ATP domain of $A B L$ (T315I) remains resistant to any kinase inhibitor until now in clinical use [2]. Thus, the search for alternative drugs effective in imatinib-resistant CML is still cogent [3]. Treatment of CML cells with histone deacetylase inhibitors (HDACi) of the class of hydroxamic acid analogues has been shown to promote proteasomal degradation of BCR/ABL [4], associated with apoptosis, and to result in anti leukemic effect together with imatinib [5], even in T315I mutation positive cells [6]. These findings prompted the design of new clinical trials with agents inhibiting Heat Shock Protein 90

\footnotetext{
* Corresponding author at: Functional Unit of Haematology, University of Florence, AUO Careggi, Largo Brambilla 3, 50134 Florence, Italy. Tel.: +39 0557947296; fax: +390557947343.

E-mail addresses: santini@unifi.it, valeria.santini@unifi.it (V. Santini).
}

(HSP90) [7], as the pivotal role of this stress-activated chaperone protein was quite clear. HSP90 in fact, in combination with HSP70 [8], contributes to protect BCR/ABL from proteasomal degradation and this activity is inactivated by chaperon protein acetylation [6,9-11]. Although histones are the most prominent and abundant substrates for HDACs, they can de-acetylate non-histone substrates, situating themselves in cell cytoplasm, nucleus and in mitochondria [12]. Candidate substrates are at least two hundred "acetylable" proteins, whose functions and localization are modulated by this post-translational modification. The mechanisms by which HDAC inhibitors may exert their broadly demonstrated antineoplastic activity could therefore lay not uniquely on their epigenetic effects [12,13].

We evaluated which protein modifications were involved in reversion of imatinib resistance by valproic acid (VPA), a feeble HDACi, belonging to the short chain fatty acid class $[14,15]$. We have recently shown that CML cells resistant to imatinib express a different protein phenotype respect to sensitive cells $[16,17]$. In this study, we support the suggestive observation of a substantial effect of HDACi/short chain fatty acids and imatinib in terms not only of inhibition of proliferation, but also BCR/ABL expression and induction of apoptosis $[17,18]$. We then present an analysis of the modifications of the acetylation and phosphorylation of proteins expressed after exposure to the combination of imatinib and VPA. To perform this analysis, we analysed human CML cell lines, with a clone resistant and a clone sensitive to ima- 
tinib and utilized a two dimensional Western blot (WB) proteomic approach [19].

\section{Materials and methods}

\subsection{Cells, drugs and culture conditions}

$B C R / A B L$ positive human cell lines K562, LAMA84 (sensitive (S) and resistant ( $R$ )) (kindly provided by Prof Gambacorti, University of Milano-Bicocca) $[1,20,21]$ and $B C R / A B L$ negative human cell line HL60 (as negative control) were grown in RPMI 1640 medium supplemented with $10 \%$ Fetal Bovine Serum (FBS) in standard conditions. BCR/ABL positive human cell lines KBM5 (parental (P) and resistant (R)) [22] (kindly provided by Dr Onida, University of Milano) were grown in IMDM medium supplemented with $10 \%$ FBS. LAMA 84 R, characterized by a 5.5 fold increase in $B C R / A B L$ mRNA and protein over production [23], were continuously grown in the presence of imatinib $0.1 \mu \mathrm{M}$; KBM5 R cells, characterized by presence of $B C R / A B L$ with T315I mutation due to substitution of threonine-to-isoleucine at position 315 of $A B L[24]$ were continuously grown in the presence of imatinib $1 \mu \mathrm{M}$. Before experiments, cells were washed thoroughly, starved for $6 \mathrm{~h}$ and exposed for $48 \mathrm{~h}$ to different doses (0.2-1 $\mu \mathrm{M}$ in sterile PBS) of imatinib mesylate (STI571, kindly provided by Novartis Pharmaceuticals) and/or HDACi valproic acid (VPA) (SanofiSynthelabo) (2 $\mathrm{mM}$ in sterile RPMI, doses with demonstrated antileukemic activity [25]).

Mononuclear cells were obtained after informed consent, routinely provided by all patients undergoing diagnostic and investigational procedures and previously approved by the local Ethical Committee. In brief, cells from bone marrow aspirates of 3 patients with CML were isolated by density gradient centrifugation with Lympholyte (CEDERLANE-Canada): samples were from 1 imatinib-sensitive patient in chronic phase (case \#1, BCR-ABL FISH: $84 \%$ positive), 1 patient at diagnosis in chronic phase (case \#2, BCR-ABL FISH: $98 \%$ positive), 1 imatinib-resistant patient in blast crisis (case \#3, BCR-ABL FISH: $100 \%$ positive) and one normal donor. All cases did not show Bcr/Abl mutations at sequencing and no additional karyotype abnormalities than $\mathrm{t}(9 ; 22)$. Primary cells were incubated for $24 \mathrm{~h}$ in the presence or the absence of imatinib $(0.2 \mu \mathrm{M}$ for normal donor and patient sensitive to imatinib, $1 \mu \mathrm{M}$ for patient resistant to imatinib in blast crisis $)$ and VPA $(2 \mathrm{mM})$ as single drug or in combination. Drugs were added to cultures at the same time.

\subsection{Cell viability and apoptosis}

The number of viable LAMA S and R cells, KBM5 P and R cells, K562 cells, HL60 cells, normal donor peripheral blood and primary CML cells at 24 (primary) and $48 \mathrm{~h}$ (cell lines) was evaluated with dye reduction WST-1 test (WST-1 Cell Proliferation Reagent, Roche Applied Science). In the same samples, apoptosis was evaluated with Annexin-V-FLUOS Staining Kit (Roche Applied Science). All samples were tested in triplicate.

\subsection{RNA extraction and $B C R / A B L$ quantification}

RNA extraction was performed by incubating with TriPure Isolation Reagent according to the manufacturer's recommendations (Roche Applied Science). Reverse transcription (RT) and Q-real-time PCR were performed using the QUANT-BCR-ABL p210 kit (Dia-Chem, Napoli, Italy) on Applied Biosystem 7300 Real Time PCR System (PE/Applied Biosystem). The cDNAs generated from RT reaction were amplified using specific primers and specific internal double-dye probe (FAM-TAMRA). Standard dilution of $B C R / A B L$ fusion cDNAs was also present in the kit to allow quantification of specific transcripts.

\subsection{Protein extraction, immunoprecipitation and Western blot analysis}

Cells were washed once with ice-cold PBS containing $100 \mu \mathrm{M} \mathrm{Na} \mathrm{VO}_{4}$ and Protease Inhibitor Cocktail (Sigma) and lysed by incubating at $95^{\circ} \mathrm{C}$ in Laemmli buffer $(62.5 \mathrm{mM}$ Tris/ $\mathrm{HCl}, \mathrm{pH} 6.8,10 \%$ glycerol, $0.005 \%$ blue bromophenol and $2 \%$ SDS). Protein concentration was determined by BCA reagent assay (Pierce). For immunoprecipitation, $500 \mu \mathrm{g}$ of proteins for each sample were used with $c$-abl antibody (Santa Cruz Biotechnology, CA, USA) and protein G agarose beads (Amersham Biosciences). Immunoprecipitated (IPs) and total proteins were separated by SDS-PAGE on $9 \%$ polyacrylamide gel and then transferred onto PVDF membranes (Hybond-ECL; Amersham Biosciences, Germany). Membranes were incubated with primary antibodies (anti-Phosphotyrosine, Cell Signalling Technology-USA, 1:1000 in PBS containing $0.1 \%$ Tween 20 and 1\% BSA (T-PBS/1\% BSA); anti-hnRNP A2/B1, Santa Cruz Biotechnology, CA, USA, $1: 1000$ in T-PBS/5\% BSA; $16-18 \mathrm{~h}$ at $4{ }^{\circ} \mathrm{C}$ ). Horseradish peroxidase (HRP) conjugate secondary antibodies anti-mouse IgG (Sigma) (1:5000 in T-PBS/5\% BSA) and anti-rabbit IgG (Sigma) (1:5000 in T-PBS/2\% $\mathrm{BSA}$ ) for $45 \mathrm{~min}$ at room temperature were employed. Immunoblots were washed in T-PBS and then developed by ECL chemiluminescence detection (Amersham Biosciences, Germany).

To verify equal loading of sample per lane, membranes were incubated with stripping buffer (62.5 mM Tris- $\mathrm{HCl}$ pH 6.7, 2\% SDS, $100 \mathrm{mM}$ 2-mercaptoethanol; $30 \mathrm{~min}$ at $50^{\circ} \mathrm{C}$ ) and, afterwards, with a $1: 1000$ dilution in T-PBS/5\% BSA of primary antibodies ( $c$-abl and anti-HSP $90 \alpha / \beta$, Santa Cruz Biotechnology, CA, USA; anti-p38,
Cell Signalling Technology-USA). HRP conjugate secondary antibody anti-rabbit IgG (Sigma) was employed.

\subsection{D-electrophoresis and Western blot}

Total cell proteins $(100 \mu \mathrm{g})$ were separated by two-dimensional (2D) electrophoresis, as previously described [26], electroblotted on PVDF membranes and incubated with anti-pan-acetylated lysine (Santa Cruz Biotechnology, 1:1000 in T-PBS/1\% BSA, $16-18 \mathrm{~h}$ at $4{ }^{\circ} \mathrm{C}$;) and anti-phospho-tyrosine (Cell Signalling Technology-USA, $1: 1000$ in T-PBS/1\% BSA; $16-18 \mathrm{~h}$ at $4{ }^{\circ} \mathrm{C}$;) primary antibodies; HRP conjugate secondary antibody anti-mouse IgG (Sigma) and anti-rabbit IgG (Sigma) was used and immunoblots were developed by ECL. For mass-spectrometry analysis, total cell protein extracts $(200 \mu \mathrm{g})$ were separated by 2D electrophoresis and stained by Colloidal Comassie G250 (Biorad). 2D gels images were analysed by Image Master Platinum Ed. software (Amersham Biosciences) and proteins from Comassie blue stained gels were matched with corresponding spots in 2D immunoblotted gels [26,27].

Protein abundance were evaluated by comparing the Spot Staining Volume as calculated by Image Master Platinum ed. Gels were run in triplicate for each sample and scatter plot $(\mathrm{v} / \mathrm{v})$ for the matching spot pools were obtained to verify the degree of reproducibility among three replicates of each sample (experiments $n=3$ ) (see Supporting information-Fig 6).

\subsection{MALDI-TOF mass spectrometry}

Spots were excised from 2D Comassie blue stained gels, de-stained and subjected to tryptic in-gel digestion with Sequencing Grade Modified Trypsin (Promega, WI) at $37^{\circ} \mathrm{C}$ for $2 \mathrm{~h}$. The resulting peptides were concentrated by Zip-Tip C18 (Millipore) and eluted directly by the Matrix solution ( $5 \mathrm{~g} / 1$ 2,5-dihydroxybenzoic acid in 50\% ACN, 0.1\%TFA) on 384-400 $\mu \mathrm{m}$ Anchor Chip Target (Bruker Daltonics, Bremen, Germany). Mass spectra for peptide mass fingerprinting were acquired in reflectron positive ion mode on Ultraflex MALDI-TOF/TOF mass spectrometer (matrix assisted laser desorption/ionization time-of-flight, Bruker Daltonics, Bremen, Germany), with an average of 100 laser shots/spectrum. Spectra were externally calibrated using a combination of four standard peptides: angiotensin Il (1046.54 Da), substance P (1347.74 Da), bombesin (1619.82 Da) and ACTH18-39 Clip human (2465.20 Da), spotted onto positions adjacent to the samples. Experimental peptide mass fingerprinting in the range of 600-3500 Da were compared with NCBI protein database by the software MASCOT (www.matrixscience.org). Confirmatory fragmentation analysis (MS/MS) was performed when needed. Investigation on protein function was conducted with NCBI Tools (Conserved Domain Database, CDD) or UniProt/TrEMBL databases.

\subsection{Statistical analysis}

Mann-Whitney test was employed to determine the significance of differences between various experimental conditions.

In order to analyse reproducibility, gel similarities or experimental variations, Scatter Plots analysis was performed by software Image Master Platinum Ed. (Amersham Biosciences) which calculates the linear dependence between spot values of one gel in comparison to another gel.

\section{Results}

\subsection{Cell viability}

We tested the ability of imatinib $(0.2 \mu \mathrm{M}$ for sensitive cells and $1 \mu \mathrm{M}$ for resistant cells) and HDACi VPA $2 \mathrm{mM}$, as single drugs and combined, to reduce viability of CML cells K562, LAMA84 S and LAMA84 R, KBM5 P and KBM5 R, as well as of negative control HL60 cells (Fig. 1A). Previously imatinib (range $0.125-1 \mu \mathrm{M}$ ), and VPA (range $0.125-2 \mathrm{mM}$ ) had been tested (data not shown). Imatinib induced a decrease of viability in sensitive cells (50\% in LAMA S and $40 \%$ in KBM5 P at $0.2 \mu \mathrm{M}$ dose) and 25\% in LAMA R at $1 \mu \mathrm{M}$ dose, but it did not have effect on KBM5 R and K562 cells. VPA as single drug inhibited K562, LAMA S and LAMA R cells, less KBM5 R viability. When imatinib was added to VPA, a significant decrease in cell viability was achieved both in sensitive and resistant cells (Fig. 1A).

\subsection{Cell apoptosis}

We then tested the ability of imatinib to enhance apoptosis in combination with VPA (Fig. 1B). Imatinib (range 0.125-1 $\mu \mathrm{M}$ ) and VPA (range $0.125-2 \mathrm{mM}$ ) were tested at escalating doses (data 

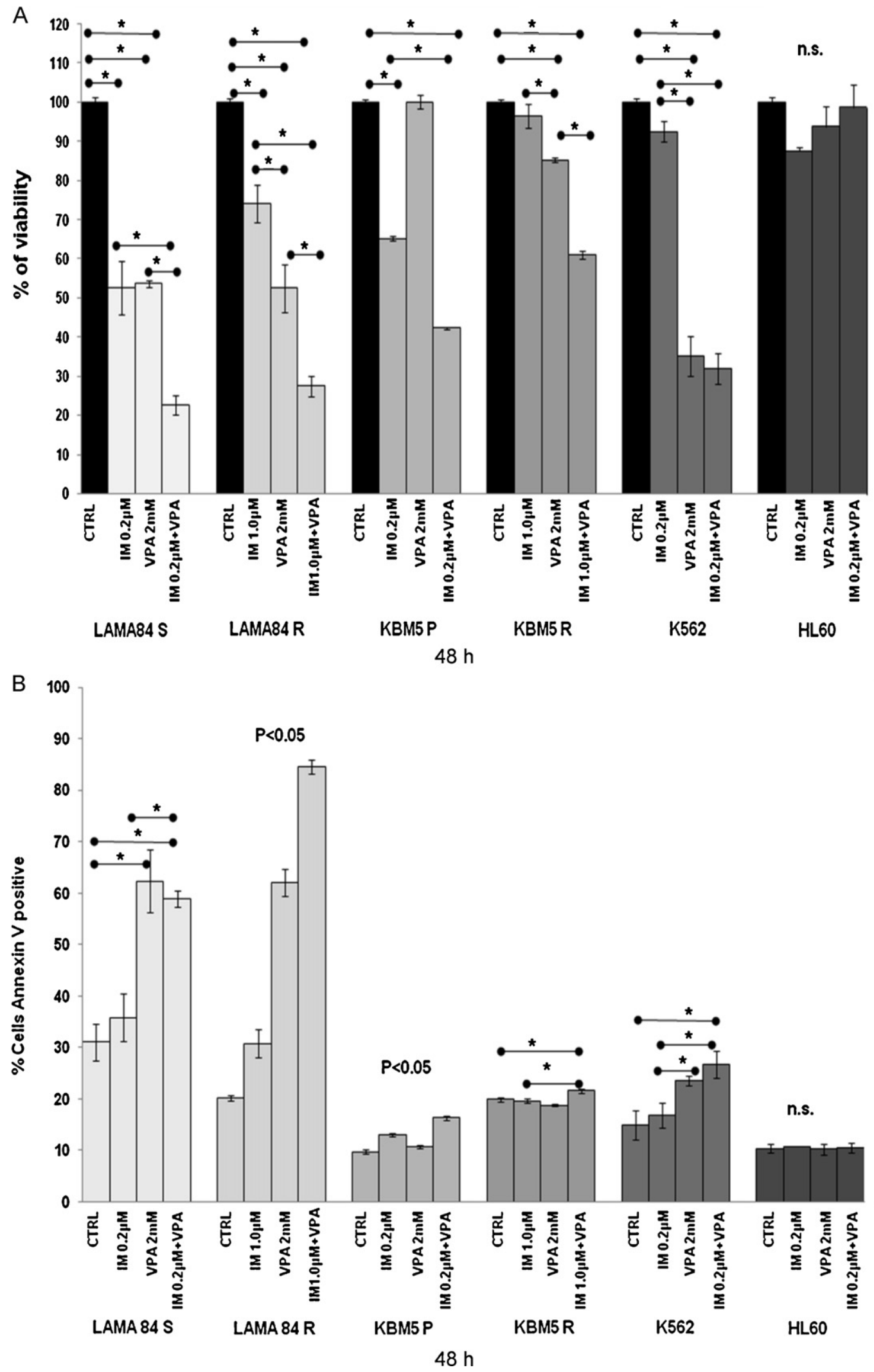

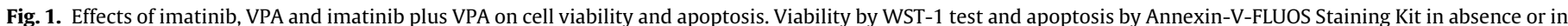

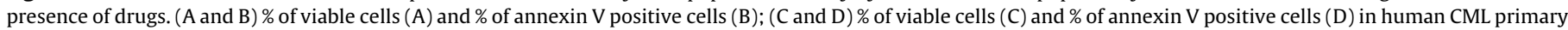

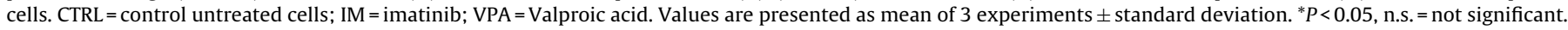



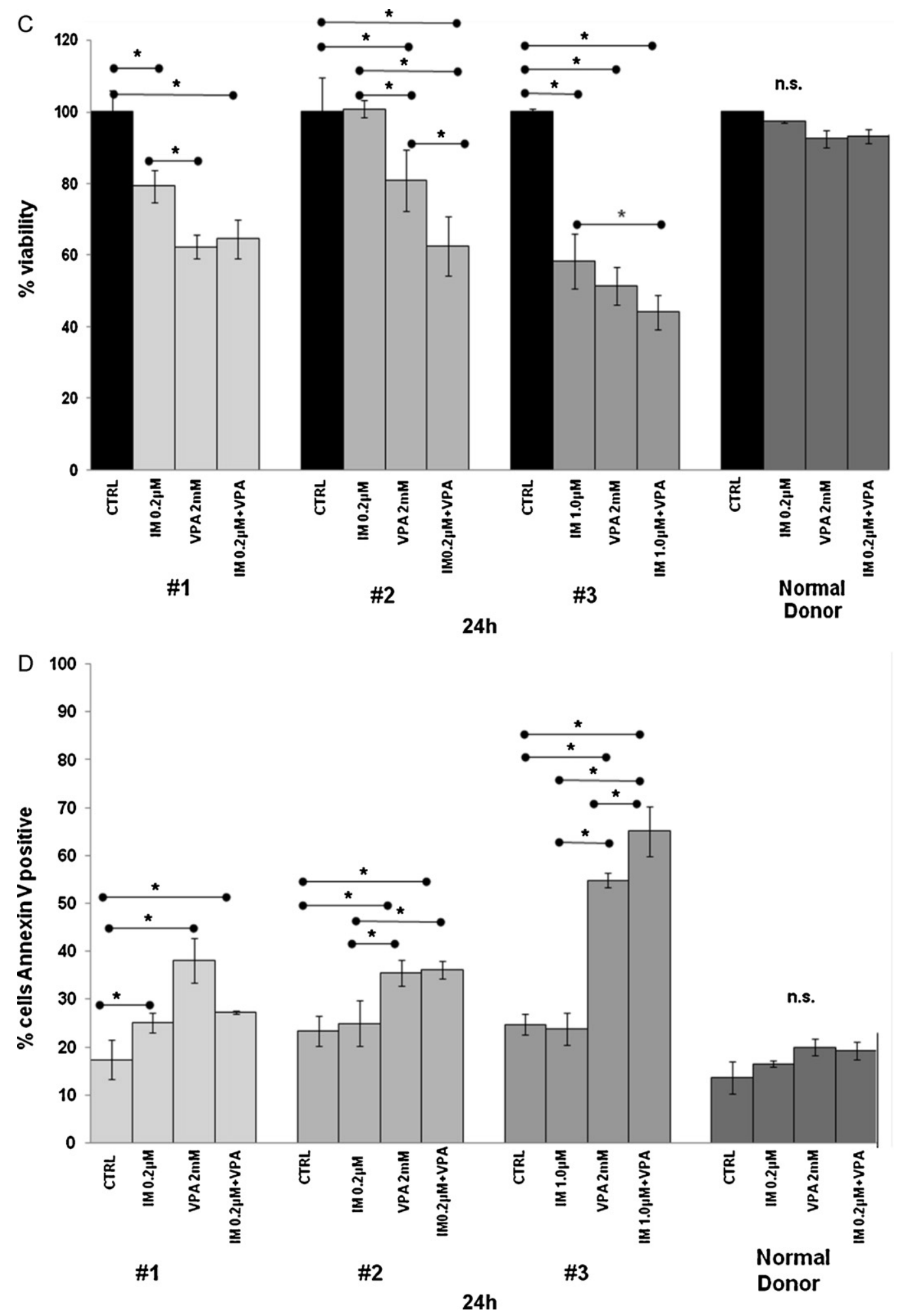

Fig. 1. (Continued)

not shown). Imatinib induced a significant increase of apoptosis in LAMA R and KBM5 P, but not in LAMA S, KBM5 R and K562. When cells were exposed to VPA, apoptosis in LAMA S, LAMA R, KBM5 P and $\mathrm{K} 562$ but not in KBM5 R was markedly induced. The combination of imatinib and VPA induced a significant increase of apoptosis in all cell lines respect to single drug treatment. As a negative control, viability and apoptosis were evaluated in HL60 cell line (Fig. 1A and B). No proper synergy was observed.

\subsection{Cell viability and apoptosis in primary CML samples}

We also analysed primary CML cases (Fig. 1C and D). After $24 \mathrm{~h}$ exposure, imatinib induced a significant decrease of viability in primary CML cells obtained from a case of imatinib-sensitive chronic phase (\#1) and from a case of imatinib-resistant blast crisis (\#3), but did not affect viability of marrow cells from another case of CML in chronic phase (\#2) (Fig. 1C). Imatinib induced a significant 


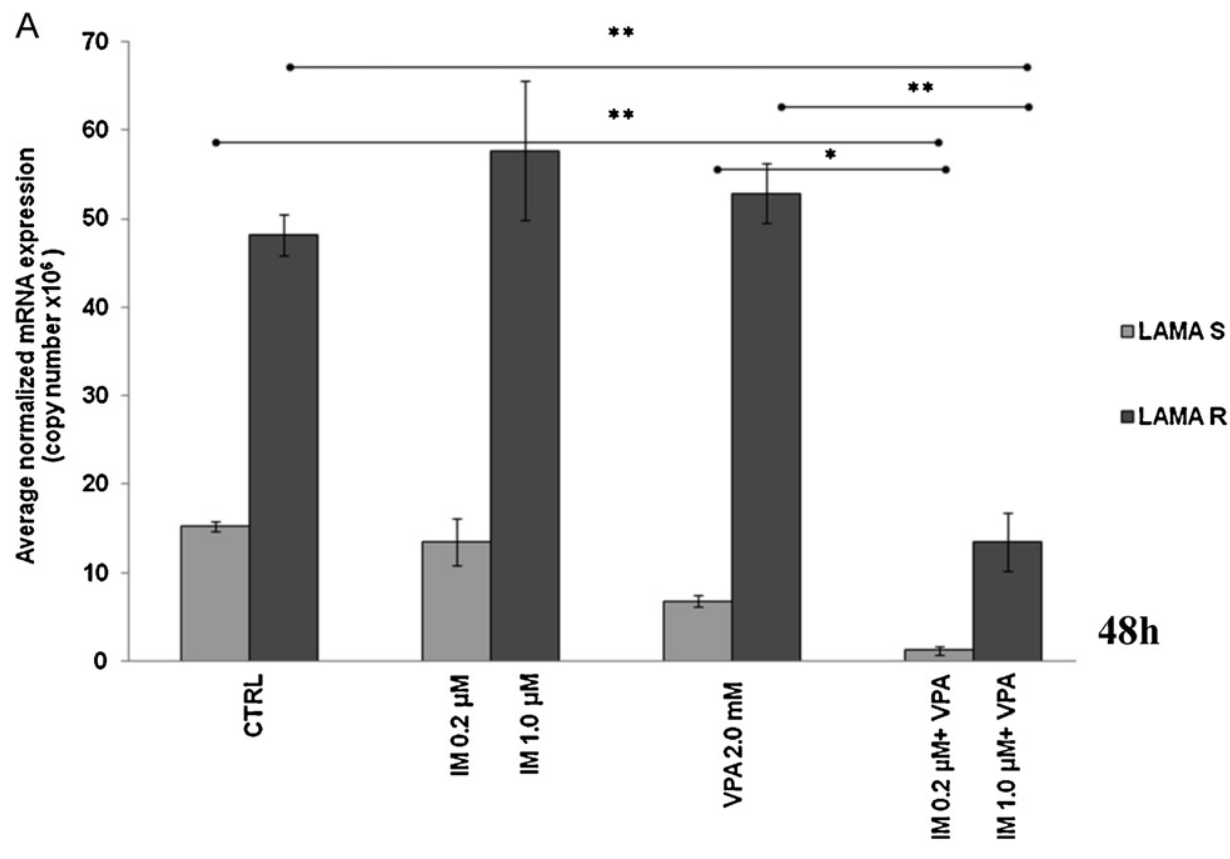

\section{BP anti-abl
WB anti Tyr Ph LAMA84S LAMA84R}

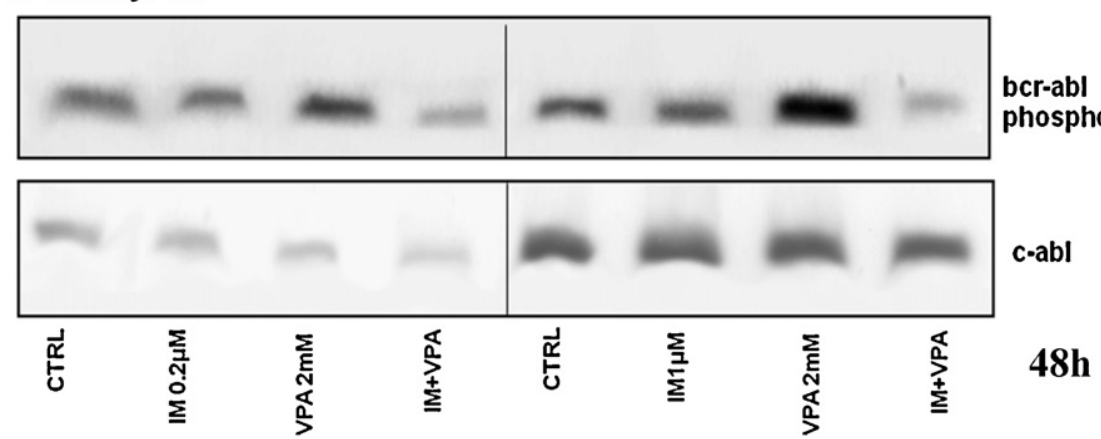

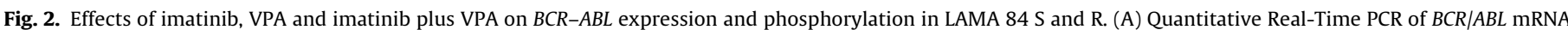

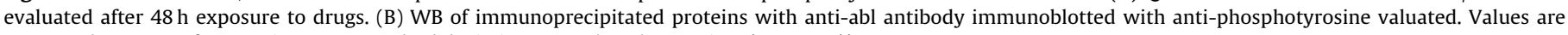
presented as mean of 3 experiments \pm standard deviation. $P Y-$ phosphotyrosine; ${ }^{*} P<0.05 ;{ }^{* *} P<0.01$.

increase of apoptosis only in imatinib-sensitive chronic phase (\#1) (Fig. 1D) but combination of imatinib and VPA induced a stronger inhibition of viability and enhancement of apoptosis in all 3 cases (Fig. 1C and D). Imatinib, VPA and imatinib plus VPA did not induce significant effects in normal donor cells (Fig. 1C and D). In all experiments, the percentage of cells in necrosis was $<10 \%$ respect to total cells.

\section{4. $B C R / A B L$ expression and activation}

\subsubsection{Q-PCR analysis}

We measured $B C R / A B L$ mRNA by quantitative real time PCR (Fig. 2A) and evaluated the phosphorylation of BCR/ABL protein by Western blot (Fig. 2B). LAMA84 S cells, exposed to imatinib $0.2 \mu \mathrm{M}$ only slightly decreased the number of copies of $B C R / A B L$ mRNA, as expected by suboptimal dose, and VPA could reduce marginally $B C R / A B L$ mRNA amount. When both low dose-imatinib and VPA were present for $48 \mathrm{~h}$ in culture, LAMA84 $\mathrm{S}$ cells produced a few copies of $B C R / A B L$ mRNA. The mechanism of imatinib resistance in LAMA84 $\mathrm{R}$ cell line is amplification of $B C R / A B L$ (about 15 copies of hybrid gene per chromosome), and our results of real-time PCR confirm it. In imatinib resistant LAMA84 cell clones, treatment with imatinib resulted in an increased transcription of $B C R / A B L$ and the addition of sole VPA did not reduce $B C R / A B L$ mRNA amount, while the combination of imatinib and VPA induced a significant decrease of $B C R / A B L$ mRNA (Fig. 2A).

\subsection{2. $B C R / A B L$ protein analysis-Western blot}

We immune-precipitated $\mathrm{BCR} / \mathrm{ABL}$ protein and evaluated its phosphorylation status after treatment with imatinib and/or VPA for $48 \mathrm{~h}$ (Fig. 2B). Proteins' loading was verified on the same membrane with anti-c-abl. In LAMA84 $\mathrm{S}$, treatment with suboptimal doses of imatinib $(0.2 \mu \mathrm{M})$ was able to reduce only marginally $\mathrm{BCR} / \mathrm{ABL}$ protein phosphorylation (68\% densitometry value respect to control phosphorylation), whereas no significant effect was seen with imatinib $1 \mu \mathrm{M}$ in LAMA84 $\mathrm{R}$ cells. This concentration of imatinib has been shown previously to be sufficient for inhibiting BCR/ABL phosphorylation in LAMA R [18], but other authors obtained results consistent with ours in terms of active concentrations of imatinib [28]. This discrepancy is probably due to differential sensitivity of diverse clones of LAMA $\mathrm{R}$ cells in culture. VPA $2 \mathrm{mM}$ slightly increased BCR/ABL activation in LAMA 84 S (119\% densitometry value respect to control phosphorylation), but highly significantly in LAMA84 R (265\% densitometry value respect to control phosphorylation). Although this increase in phosphorylation is difficult to explain, when cells were 


\section{anti Pan-AcetylLys}

LAMA 84 S

A
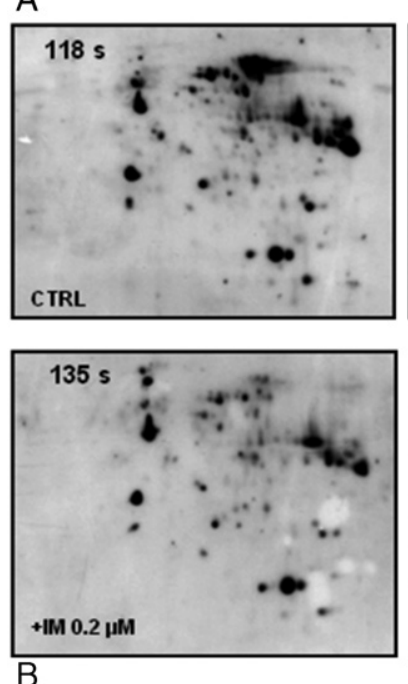

C
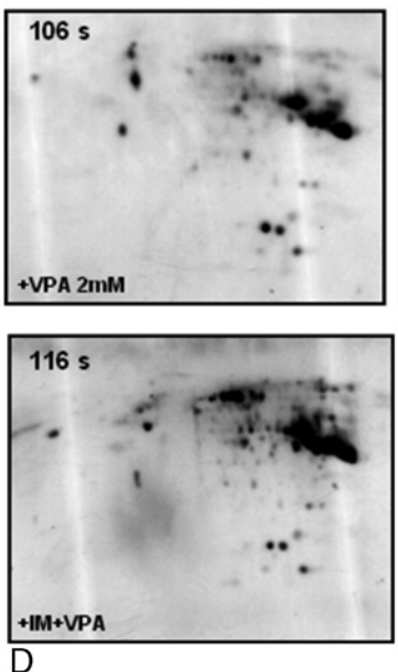

LAMA $84 R$
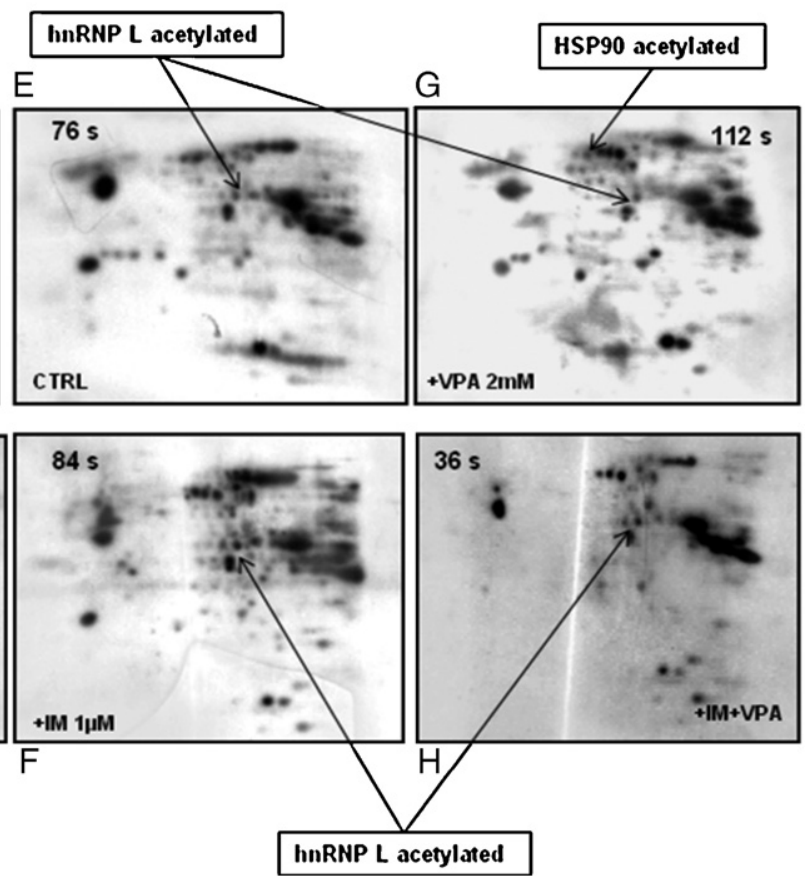

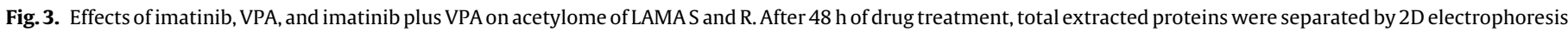
and immunoblotted with anti-pan-acetylated lysine antibody. Proteins showing modified acetylation after treatment are indicated.

exposed to combination of VPA and imatinib, BCR/ABL phosphorylation was profoundly inhibited in both $S$ and $R$ cell clones (37\% in sensitive and $25 \%$ in resistant cells respect to control phosphorylation).

\subsection{Acetylome analysis}

\subsubsection{D-electrophoresis and immunoblot anti-acetylated lysine}

We analysed post-translational modifications of proteome in CML cell lines LAMA84 $\mathrm{S}$ and LAMA84 R after treatment with VPA in combination with imatinib for $48 \mathrm{~h}$. We validated 2D electrophoresis and mass spectrometry (MS) analysis in terms of reproducibility, as we had already done in our previous work [16]. In the antipan acetylated WB blots (Fig. 3) we detected 118 clear spots for the imatinib-sensitive cells (Fig. 3A) and 76 for imatinib-resistant cells (Fig. 3E) corresponding to acetylated proteins. Imatinib exposure for $48 \mathrm{~h}$ did not influence proteins acetylation compared with untreated cells ( 135 spots in LAMA S (Fig. $3 \mathrm{~B}$ ) and 84 spots in LAMA $\mathrm{R}$ (Fig. 3F). In LAMA $\mathrm{S}$ cells treated for $48 \mathrm{~h}$ with VPA $2 \mathrm{mM}$ the number of acetylated spots was 106 (Fig. 3C) and in LAMA R 112 (Fig. 3G). LAMA $84 \mathrm{~S}$ cells treated with combination of imatinib and VPA demonstrated 116 spots (Fig. 3D), while for LAMA84 R cells were detected 36 spots (Fig. $3 \mathrm{H}$ ). When we measured global acetylation by densitometry (summing single spot densitometry value), we could not detect appreciable changes for LAMA $S$ cells treated with VPA or imatinib, and with VPA plus imatinib, 94\% $( \pm 1.3$ standard deviation $-\mathrm{SD}), 103 \%( \pm 1.05 \mathrm{SD})$ and $101 \%( \pm 1.1$ $\mathrm{SD}$ ) of control levels, respectively. On the contrary, global protein acetylation was increased in LAMA R cells by the treatment with VPA, 178\% ( $\pm 1.9 \mathrm{SD})$ respect to control untreated cells, according to increase of number spots. Imatinib was not able to increase the number and level of acetylated spots $(105 \%, \pm 1.1 \mathrm{SD})$ but combination of imatinib and VPA lead a decrease of both global acetylation (51\%, $\pm 0.5 \mathrm{SD})$.

\subsubsection{Identification of single protein} spots-immunoblot/Comassie gel match and mass spectrometry

Matching of Blue Comassie stained gels and immunoblotted gels was performed by direct superimposition and spots were picked when differently acetylated or expressed than those present on control gels [19]. When mass spectrometry was applied, the picked spots were analysed and 23 common proteins to LAMA S and LAMA R cells were identified and studied (Table 1 ). Ratio of densitometry values of correspondent acetylated spots in imatinib (IM), valproic acid (VPA) and imatinib plus valproic acid (IM + VPA) treated cells respect to untreated cells $(C)$ was calculated.

Treatment with VPA decreased HSP90 expression in LAMA84 $\mathrm{R}$ cells (Fig. 4), but at the same time induced a robust acetylation (Fig. 3G) (ratio VPA treated cells/untreated cells of HSP90 acetylation $=16.17$ - Table 1). Treatment with imatinib plus VPA inhibited both HSP90 expression and acetylation (Fig. 3H, Fig. 4 and Table 1).

We also observed a significant decrease of hnRNP L expression in LAMA R after treatment with imatinib plus VPA (Fig. 4) and an acetylation increase particularly evident after combined treatment (ratio CTRL/IM + VPA = 5.15 - Table 1) (Fig. 3H).

\subsection{Phosphoproteome analysis}

\subsubsection{D-electrophoresis and immunoblot anti-phosphorylated tyrosine}

Phospho-proteome modifications of LAMA84 S and LAMA84 R are particularly complex to elaborate. We detected 164 spots in untreated LAMA S cells (Fig. 5A, a) and 150 spots in untreated LAMA $\mathrm{R}$ cells (Fig. 5A, e) corresponding to phosphorylated proteins. In LAMA $S$ cells treated with imatinib for $48 \mathrm{~h}$, the number of phosphorylated spots was 119 (Fig. 5A, b), while in LAMA R was 206, as expected for a reactive effect to drug exposure (Fig. 5A, f). VPA $2 \mathrm{mM}$ influenced minimally phosphorylation (162 spots in LAMA $\mathrm{S}$ (Fig. 5A, c) and 145 in LAMA R (Fig. 5A, g). The combination of 
Table 1

Modifications in acetylation of proteins, as identified by mass spectrometry after in vitro treatment with VPA and imatinib.

\begin{tabular}{|c|c|c|c|c|c|c|c|c|c|c|}
\hline \multirow[t]{2}{*}{ ID } & \multirow[t]{2}{*}{ Protein name } & \multirow[t]{2}{*}{ Score $^{\mathrm{a}}$} & \multirow[t]{2}{*}{$\mathrm{MW}^{\mathrm{b}}$} & \multirow[t]{2}{*}{$\mathrm{pI}^{\mathrm{c}}$} & \multicolumn{3}{|c|}{ LAMA S } & \multicolumn{3}{|c|}{ LAMA R } \\
\hline & & & & & $\mathrm{IM} / \mathrm{C}$ & $\mathrm{VPA} / \mathrm{C}$ & $\mathrm{IM}+\mathrm{VPA} / \mathrm{C}$ & $\mathrm{IM} / \mathrm{C}$ & $\mathrm{VPA} / \mathrm{C}$ & $\mathrm{IM}+\mathrm{VPA} / \mathrm{C}$ \\
\hline gi|31615559 & $\begin{array}{l}\text { Chain B, X-ray crystal structure of } \\
\text { cyclophilin A HIV-1 }\end{array}$ & 96 & 18156 & 8.34 & 1.01 & 0.08 & n.d. ${ }^{d}$ & 0.64 & 1.74 & 0.2 \\
\hline gi|2981764 & $\begin{array}{l}\text { Peptidylprolil isomerase A } \\
\text { (cyclophilin A) }\end{array}$ & 124 & 18154 & 7.82 & 1 & 0.43 & 0.24 & 0.29 & 1.09 & 0.17 \\
\hline gi|30582531 & Cofilin 1 (non-muscle) & 100 & 18775 & 8.22 & 1.38 & 1.94 & 1.24 & 4.04 & 10.38 & 4.11 \\
\hline gi|5542166 & Chain $\mathrm{B}, \mathrm{H}$ platelet profilin & 66 & 15056 & 8.47 & 0.63 & 0.66 & 0.43 & 1.75 & 3.16 & 1.16 \\
\hline gi|55959886 & Peroxiredoxin 1 & 190 & 22380 & 8.27 & 0.92 & 0.36 & 0.34 & 1.63 & n.d. & n.d. \\
\hline gi $\mid 55958716$ & High-mobility group box 1 & 60 & 22249 & 9.61 & 0.52 & 0.16 & n.d. & 0.93 & 5.59 & 0.26 \\
\hline gi|17389815 & Triosephosphate isomerase 1 & 203 & 26980 & 6.45 & 0.86 & 0.91 & 0.43 & 0.54 & 2.27 & 0.95 \\
\hline gi|75517570 & hnRNP A1 & 67 & 34317 & 9.19 & 0.43 & 0.98 & 0.95 & 0.24 & 0.82 & 0.84 \\
\hline gi $\mid 55633947$ & Similar to hnRNP H3 isoform a & 83 & 36974 & 6.37 & 0.72 & 1.12 & 1 & 1.62 & 2.1 & 1.13 \\
\hline gi $\mid 46812638$ & hnRNP L & 61 & 60977 & 6.65 & 0.45 & 0.35 & 0.28 & 1.84 & 1.96 & 5.15 \\
\hline gi| 16876910 & hnRNP F & 60 & 46097 & 5.38 & 0.14 & n.d. & 0.47 & 1 & 1.2 & 0.9 \\
\hline gi|4930291 & Fructose bisphosphate aldolase A & 228 & 39833 & 8.39 & 0.56 & 1.11 & 0.87 & 0.87 & 1.69 & 0.95 \\
\hline gi|62897945 & Enolase 1 variant & 175 & 47594 & 7.01 & 0.43 & 0.47 & 0.28 & 1.35 & 0.7 & n.d. \\
\hline gi|840693 & Coproporphirinogen oxidase & 62 & 40976 & 6.65 & 0.38 & n.d. & 1.25 & 1.23 & 4.16 & 1.1 \\
\hline gi|999893 & Triosephosphate isomerase 1 (Tim) & 190 & 26877 & 6.51 & 0.65 & 0.55 & 0.41 & n.d. & n.d. & n.d. \\
\hline gi|55959292 & Annexin A1 & 47 & 38974 & 6.57 & n.d. & n.d. & 0.42 & 0.6 & 1.27 & 1.75 \\
\hline gi|54696794 & $\begin{array}{l}\text { Chaperonin containing TCP1, } \\
\text { subunit } 2 \text { (beta) }\end{array}$ & 59 & 57878 & 6.01 & 0.71 & n.d. & 0.81 & 1.26 & 0.82 & 3.81 \\
\hline gi|15215418 & Heat shock $90 \mathrm{kDa}$ protein 1 , beta & 264 & 83638 & 4.97 & n.d. & n.d. & n.d. & n.d. & 16.17 & n.d. \\
\hline gi|54696884 & $\begin{array}{l}\text { Stress-induced-phosphoprotein } 1 \\
\text { (Hsp70/Hsp90-org protein) }\end{array}$ & 273 & 63381 & 6.4 & 0.4 & 0.7 & 0.28 & 0.6 & 1.75 & 1.8 \\
\hline gi|55960373 & Transgelin 2 & 271 & 22590 & 8.41 & 0.63 & 0.25 & 0.26 & 3.2 & 1.67 & 1.49 \\
\hline gi|2055427 & KSRP & 48 & 73542 & 6.84 & 0.05 & 0.16 & 0.11 & 1.82 & 2.1 & 2.8 \\
\hline gi|54648253 & KSRP & 64 & 73420 & 8 & 0.21 & 0.07 & n.d. & 1.9 & 2.15 & 5 \\
\hline gi|30582861 & $\begin{array}{l}\text { Nucleophosmin (nucleolar } \\
\text { phosphoprotein B23, numatrin) }\end{array}$ & 75 & 32768 & 4.64 & 0.19 & 0.42 & 1.54 & 0.86 & 1.66 & 2.56 \\
\hline
\end{tabular}

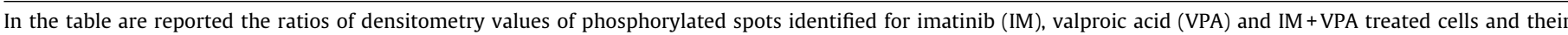

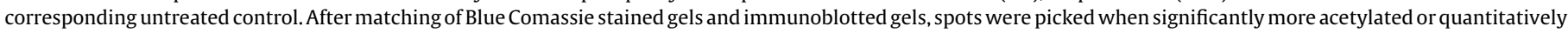
different than those present on gels of control not treated cells see methods).

a Score - significance index calculated by MASCOT.

b MW - molecular weight.

c $\mathrm{pI}$ - isoelectric point.

d n.d. - not detected.

\section{LAMA R}

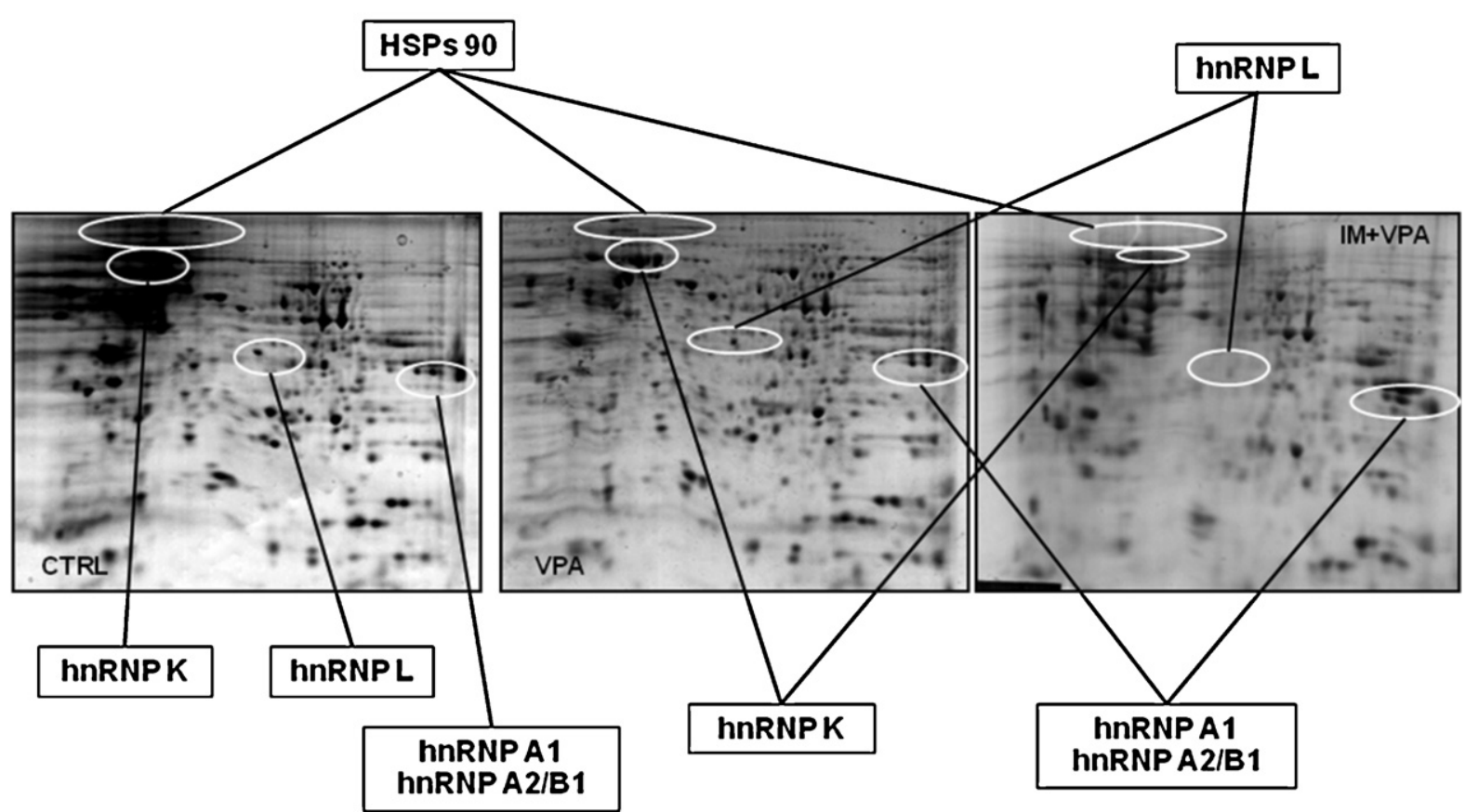

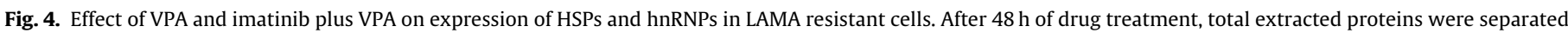

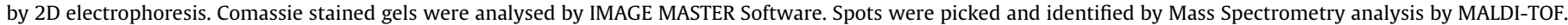
Proteins differently expressed after treatments are indicated. 
A

\section{anti Phosphotyrosine}

LAMA84 S
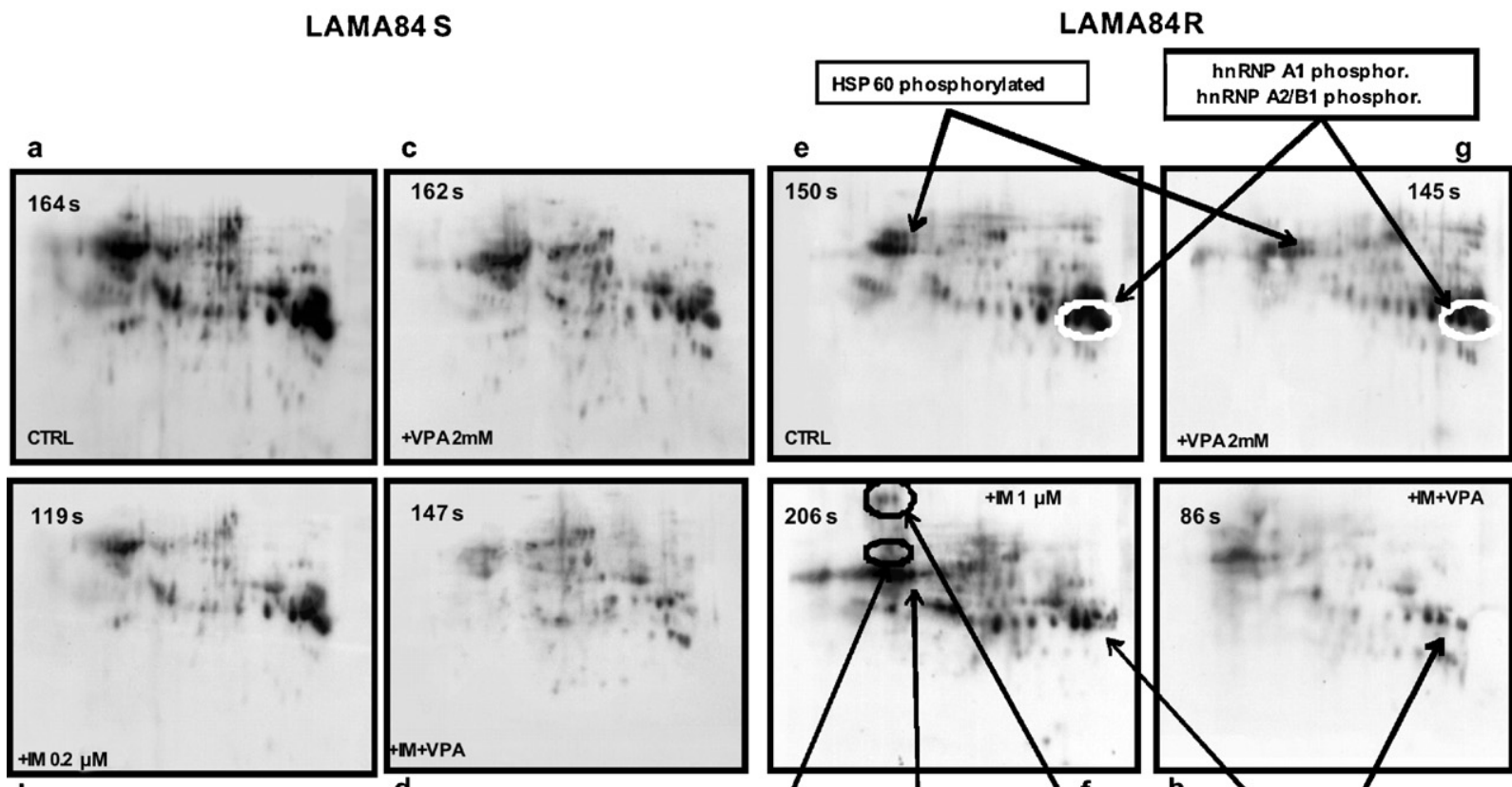

b
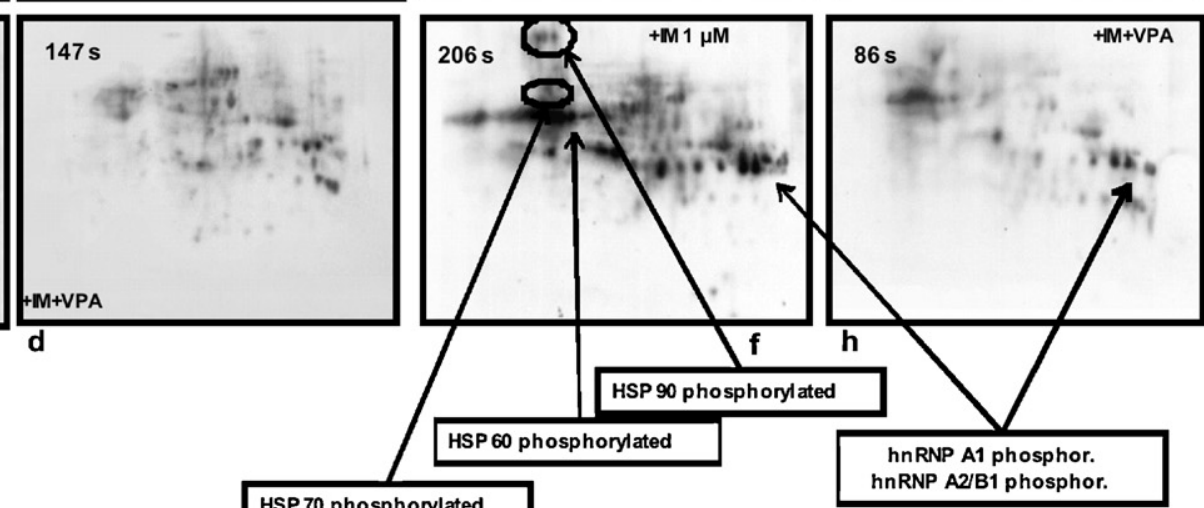

HSP 70 phosphorylated

B

LAMAR
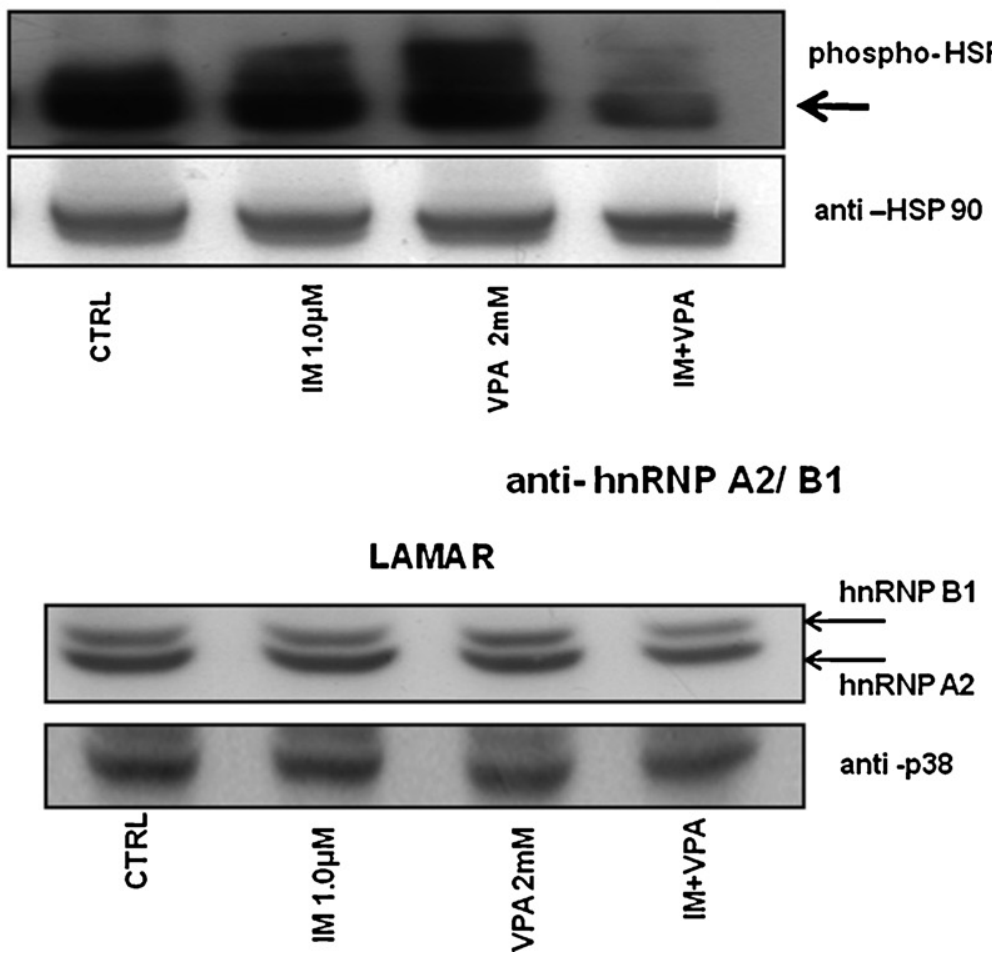

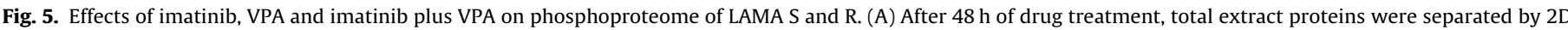

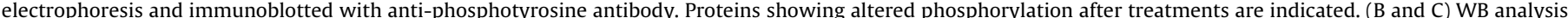

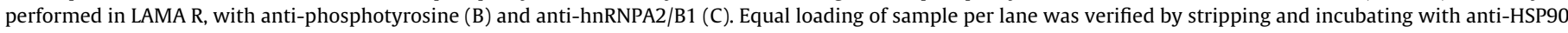
(B) and anti-p38 (C) antibodies. 
Table 2

Modifications in phosphorylation of proteins, as identified by mass spectrometry after in vitro treatment with VPA and imatinib.

\begin{tabular}{|c|c|c|c|c|c|c|c|c|c|c|}
\hline \multirow[t]{2}{*}{ ID } & \multirow[t]{2}{*}{ Protein name } & \multirow[t]{2}{*}{ Score $^{a}$} & \multirow[t]{2}{*}{$\mathrm{MW}^{\mathrm{b}}$} & \multirow[t]{2}{*}{$\mathrm{pI}^{\mathrm{c}}$} & \multicolumn{3}{|c|}{ LAMA S } & \multicolumn{3}{|c|}{ LAMA R } \\
\hline & & & & & $\mathrm{IM} / \mathrm{C}$ & $\mathrm{VPA} / \mathrm{C}$ & $\mathrm{IM}+\mathrm{VPA} / \mathrm{C}$ & $\mathrm{IM} / \mathrm{C}$ & $\mathrm{VPA} / \mathrm{C}$ & $\mathrm{IM}+\mathrm{VPA} / \mathrm{C}$ \\
\hline gi|15215418 & Heat shock 90 kDa protein 1, beta & 89 & 83638 & 4.97 & 0.3 & n.d. ${ }^{\mathrm{d}}$ & n.d. & IM & n.d. & n.d. \\
\hline gi|62087882 & Heat shock $70 \mathrm{kDa}$ protein 4 isoform a variant & 97 & 89015 & 5.44 & n.d. & n.d. & n.d. & IM & n.d. & n.d. \\
\hline gi|5729877 & Heat shock 70 kDa protein 8 isoform 1 & 123 & 71138 & 5.37 & 0.8 & 1.1 & 0.2 & 0.3 & 0.1 & 0.1 \\
\hline gi|31542947 & Heat shock $60 \mathrm{kDa}$ protein 1 , beta & 43 & 61229 & 5.7 & 0.5 & 1.2 & n.d. & 1.4 & 0.5 & n.d. \\
\hline gi|15277503 & ACTB protein & 110 & 40620 & 5.55 & n.d. & n.d. & n.d. & 0.1 & 0.4 & 0.8 \\
\hline gi|62897681 & Calreticulin precursor variant & 54 & 47103 & 4.3 & 0.9 & 0.8 & 0.2 & 1.8 & 1.4 & n.d. \\
\hline gi|62897409 & Beta actin variant & 71 & 42122 & 5.29 & 0.4 & 1.1 & n.d. & 2.4 & 0.4 & 0.4 \\
\hline gi|75517570 & hnRNP A1 & 89 & 29510 & 9.19 & 0.3 & 1.1 & 0.6 & 0.9 & 1.4 & n.d. \\
\hline gi|4504447 & hnRNP A2 & 105 & 36055 & 8.67 & 0.4 & 0.8 & 0.0 & 0.9 & 1.4 & n.d. \\
\hline gi|4930291 & Fructose bisphosphate aldolase A & 175 & 39833 & 8.39 & 0.7 & 0.8 & 0.5 & 0.8 & 0.9 & n.d. \\
\hline gi|7669492 & Glyceraldehyde 3 phosphate dehydrogenase & 65 & 36244 & 8.57 & 0.4 & 0.8 & 0.0 & 0.9 & 1.0 & n.d. \\
\hline gi|31645 & Glyceraldehyde 3 phosphate dehydrogenase & 43 & 36244 & 8.26 & 0.4 & 0.8 & 0.0 & 0.9 & 1.4 & n.d. \\
\hline gi|4679012 & Lysophospholipase isoform & 57 & 23287 & 6.05 & 0.4 & 0.9 & n.d. & n.d. & n.d. & 0.9 \\
\hline gi|46360168 & Prohibitin & 177 & 29857 & 5.57 & 0.7 & n.d. & 0.3 & n.d. & n.d. & n.d. \\
\hline gi|30582861 & Nucleophosmin (nucleolar phosphoprotein B23) & 75 & 32768 & 4.3 & 0.9 & 0.8 & 0.2 & 1.8 & 1.4 & n.d. \\
\hline
\end{tabular}

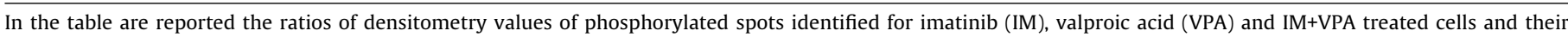

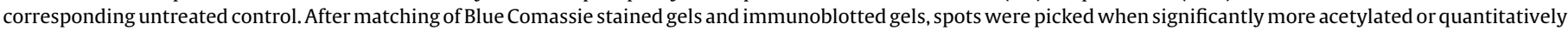
different than those present on gels of control not treated cells see methods).

a Score - significance index calculated by MASCOT.

b MW - molecular weight.

c $\mathrm{pI}$ - isoelectric point.

d n.d. - not detected.

imatinib and VPA markedly reduced the number of phosphorylated spots (147 spots in LAMA S (Fig. 5A, d) and 86 in LAMA R (Fig. 5A, h)).

Level of total phosphorylation was measured by densitometry and a marked decrease of phosphorylation, calculated respect to control gels, was observed in imatinib treated LAMA S cells (66\%, $\pm 0.9 \mathrm{SD})$, but also in VPA treated cells (73\%, $\pm 1.3 \mathrm{SD})$. In LAMA $\mathrm{R}$ cells, global phosphorylation was induced by imatinib (125\%, \pm 1.1 SD) but not by VPA (109\%, \pm 1.3 SD). Maximal inhibition of total phosphorylation was observed if this HDACi was combined with imatinib (41\%, \pm 1.1 SD in LAMA S and $65 \%, \pm 0.9$ SD in LAMA R).

\subsubsection{Identification of single protein}

spots-immunoblot/Comassie gel match and mass spectrometry

Matching of gels was performed as above specified for acetylome, and 15 proteins identified as differentially phosphorylated (Table 2). We identified HSP90, HSP70 and HSP60 which phosphorylation was induced by imatinib in LAMA R cells (Fig. 5A, f); treatment with VPA inhibited phosphorylation of HSP90 and HSP70 and decreased phosphorylation of HSP60 (Fig. 5A, g). Combination of IM and VPA maintained these proteins de-phosphorylated (Fig. 5A, h). To confirm the decrease of HSP90 phosphorylation in LAMA R, Western blot analysis was performed (Fig. 5B).

We observed, moreover, an increase of hnRNP A1 and hnRNP A2 phosphorylation in LAMA R after treatment with VPA (Fig. 5A, g), but imatinib plus VPA inhibited phosphorylation of these proteins (Fig. 5A, h). At the same time, we observed that, in LAMA R cells, treatment with VPA and imatinib plus VPA induced a decrease of some hnRNPs expression respect to untreated cells (Fig. 4). We investigated the modification of hnRNP A2 and hnRNP B1 expression by Western blot analysis and our results showed that in LAMA $\mathrm{R}$ single drugs did not induce modification of expression but a significant decrease was observed after treatment with imatinib plus VPA (Fig. 5C).

\section{Discussion}

Patients with CML have in the great majority of cases an excellent clinical, cytogenetic and molecular response to imatinib, but some may result refractory or loose clinical response because of innate or acquired resistance, caused by amplification of the
$B C R-A B L$ genomic locus or more frequently by point mutations within the kinase domain of $\mathrm{BCR}-\mathrm{ABL}$, which prevent imatinib binding [2]. Even if new tyrosine kinase inhibitors are in use (dasatinib [29], nilotinib[30], bosutinib [31]), still there is an unmet need to identify other molecular targets whose inactivation could contribute to the eradication of the CML clone/clones. In fact, different essential pathways like cytoskeleton organization [32], cell mitosis [33] and apoptosis [34] are modified by the presence of BCR/ABL protein. Nevertheless, modifications in cell metabolism determined by the development of imatinib resistance and the detailed molecular mechanisms involved in this event still remain unclear. Proteome analysis of CML cells is just starting to be published in the last few years and data are still scanty [16,35-37]. Our previous work has clarified proteome alterations in imatinib resistant versus sensitive LAMA84 chronic myeloid leukaemia cells, and we have published the identification of four classes of proteins which were significantly different in resistant versus sensitive cells: (1) HSPs and chaperones, (2) nucleic acid binding/synthesis/stability, (3) structural proteins (4) cell signalling [16]. Imatinib has been combined with other drugs (i.e. HDAC inhibitors, bortezomib [38], interferon [39]) and some of these combinations have been successful in restoring imatinib sensitivity in CML. Especially co-treatment with imatinib and also other tyrosine kinase inhibitors (TKI) and HDACi (SAHA, LBH589) looks promising [4,5,14,40].

We observed, both in cell-lines and in primary CML cells, that VPA induced a decrease of viability and an increase of apoptosis. Combined treatment of suboptimal dose of imatinib and VPA was effective, confirming what already shown by other authors [17]. It is extremely intriguing that such activity of VPA is more pronounced in CML cells resistant to imatinib than in sensitive ones.

We hypothesized that the mechanism by which VPA restores sensitivity to the tyrosine kinase inhibitor may be mediated not only by chromatin remodelling and transcriptional regulation but also by acetylation and subsequent inactivation of HSP proteins [4] and by modification of critical protein expression (ribosomal shuttle proteins, cycle regulators, cytoskeleton proteins).

We therefore studied protein expression and post-translational modifications of proteome in LAMA84 R and LAMA84 S cells by 2D electrophoresis.

In LAMA R acetylation of some proteins was evidently induced by VPA: cofilin-1, profilin, high mobility group box-1, copro- 
porphirinogen oxidase and Hsp90 $\beta$. Though total acetylation decreased globally after treatment with VPA plus imatinib, three proteins, hnRNP L, chaperonin containing TCP1 and KSRP, showed a significant increase in acetylation. Such acetylation could alter their function of shuttle and chaperonin proteins [12,13,41]. We found, in fact that VPA decreased expression and increased acetylation of HSP90 $\beta$ (ratio acetylation VPA treated cells/untreated cells $=16.17$ - Table 1 ). The involvement of HSP90 and indirectly of HSP70 in imatinib resistance had been demonstrated before $[9,16]$. Broad involvement of HSPs could in fact represent a common shared mechanism in tumour progression. Heat Shock Proteins are inactivated by acetylation and this impairs the interaction with the client protein BCR/ABL, promoting its proteasomal degradation $[4,5,41]$. In our opinion these findings are particularly relevant because indicate that VPA (similarly to SAHA) may interfere with chaperone protein-driven mechanism of imatinib resistance both by inhibiting cytoplasmic HSP90 expression and by acetylating it.

We observed, for the first time in our knowledge, a marked modulation of heterogeneous nuclear ribonucleoproteins (hnRNPs) expression and post translational modifications following VPA treatment. HnRNPs are involved in several RNA-related biological processes such as transcription, pre-mRNA processing, mature mRNA transport to the cytoplasm and translation [42]. In $B C R / A B L-$ expressing cells, there is a marked increase in the levels of hnRNPs [43]. BCR/ABL oncoproteins are involved in post-transcriptional regulation via hnRNP shuttling proteins. Transcriptional or posttranscriptional regulation might be the primary mechanism for controlling the levels and/or the activity of certain BCR/ABL effectors and might, in part, explain why the balance between proliferation, differentiation, and apoptosis is completely subverted in CML blast crisis [43]. Particularly, we had detected quantitative increase of 3 hnRNPs in LAMA $84 \mathrm{R}$ respect to LAMA $84 \mathrm{~S}$ [16], whose importance and significance in stabilizing and shuttling the message of BCR/ABL oncoprotein seems fundamental to determine imatinib resistant phenotype. The hnRNP $\mathrm{K}$ was expressed only in LAMA R [16] and after treatment with VPA and imatinib plus VPA the expression was inhibited. Consistently with our observations, hnRNP K expression and sub cellular localization were recently shown to be directly related to Bcr/Abl presence and proliferation, clonogenic potential, and in vivo leukaemogenic activity of BCR/ABL-expressing myeloid cells [44].

We also investigated modifications of phosphoproteome in LAMA cell-lines after treatment with imatinib and VPA. We observed an expected increase in protein phosphorylation in imatinib-treated LAMA R cells. In cells transformed by BCR/ABL, hnRNP A1 expression is markedly up-regulated [43]. We showed an inhibition of hnRNP A1 expression and phosphorylation after treatment with imatinib plus VPA in LAMA R. HnRNP A1 is a protein that shuttles continuously between the nucleus and the cytoplasm, where it dissociates from its mRNA cargo and is rapidly re-imported into the nucleus. It is tempting to speculate that also tyrosine phosphorylation could interfere with the assembly of multiprotein complexes targeting RNA-binding proteins for proteasome-dependent degradation.

In our opinion, the nature of the proteins (nucleus-cytoplasm shuttle and chaperonins) that we found post-translational modified in CML cells after VPA, and imatinib plus VPA, renders our findings particularly relevant and intriguing. VPA induced re-acquisition of sensitivity to imatinib is paralleled by modification of acetylation of both cytoplasmic and nuclear non-histone proteins, similarly to what has been shown for more potent HDACi like SAHA. We show here that not only HSPs, but that several cytoplasmic proteins essential for cell proliferation and mRNA stabilization are acetylated by VPA, and that combined treatment with imatinib, induces acetylation of hnRNP L.
Although the effects of VPA in combination with imatinib have been observed earlier, our work constitutes the first attempt to analyze the effect of this HDACi on cellular proteome and the mechanism of cooperative effect.

Evidently, we identified proteins, HSPs and hnRNPs, whose induction of post-translational modifications parallels restoration of imatinib sensitivity. These proteins potentially play a relevant role in imatinib resistance and this role can be modulated by VPA as demonstrated by 2D Western blot.

\section{Conflict of interest}

All authors have no conflict of interest to declare.

\section{Acknowledgements}

Ente Cassa di Risparmio di Firenze (ECR) (R.Pastorelli was recipient of an ECR fellowship). Research Fundings: Ministero per l'Istruzione, l'Università e la Ricerca (MIUR). We thank Gloriano Moneti, Centro Interdipartimentale di Spettrometria di Massa (C.I.S.M.), University of Florence.

Authors' contributions: FB, RP, DT and VS contributed equally to this work; FB and RP preformed experiments and wrote the results section; GF performed mass spectrometry analysis; VS and DT designed the study and wrote the manuscript; ES performed Western blot experiments and FS, AG and AB collected the samples from CML patients and organized the results.

\section{Appendix A. Supplementary data}

Supplementary data associated with this article can be found, in the online version, at doi:10.1016/j.leukres.2011.01.033.

\section{References}

[1] Gambacorti-Passerini CB, Gunby RH, Piazza R, Galietta A, Rostagno R, Scapozza L. Molecular mechanisms of resistance to imatinib in Philadelphiachromosome-positive leukaemias. Lancet Oncol 2003;4:75-85.

[2] Kantarjian HM, Talpaz M, Giles F, O’Brien S, Cortes J. New insights into the pathophysiology of chronic myeloid leukemia and imatinib resistance. Ann Intern Med 2006;145:913-23.

[3] Jabbour E, Cortes JE, Ghanem H, O'Brien S, Kantarjian HM. Targeted therapy in chronic myeloid leukemia. Expert Rev Anticancer Ther 2008;8: 99-110.

[4] Nimmanapalli R, Fuino L, Bali P, Gasparetto M, Glozak M, Tao J, et al. Histone deacetylase inhibitor LAQ824 both lowers expression and promotes proteasomal degradation of Bcr-Abl and induces apoptosis of imatinib mesylate-sensitive or -refractory chronic myelogenous leukemia-blast crisis cells. Cancer Res 2003;63:5126-35.

[5] Nimmanapalli R, Fuino L, Stobaugh C, Richon V, Bhalla K. Cotreatment with the histone deacetylase inhibitor suberoylanilide hydroxamic acid (SAHA) enhances imatinib-induced apoptosis of Bcr-Abl-positive human acute leukemia cells. Blood 2003;101:3236-9.

[6] Peng C, Brain J, Hu Y, Goodrich A, Kong L, Grayzel D, et al. Inhibition of heat shock protein 90 prolongs survival of mice with BCR-ABL-T315I-induced leukemia and suppresses leukemic stem cells. Blood 2007;110:678-85.

[7] Solit DB, Ivy SP, Kopil C, Sikorski R, Morris MJ, Slovin SF, et al. Phase I trial of 17-allylamino-17-demethoxygeldanamycin in patients with advanced cancer. Clin Cancer Res 2007;13:1775-82.

[8] Guo F, Rocha K, Bali P, Pranpat M, Fiskus W, Boyapalle S, et al. Abrogation of heat shock protein 70 induction as a strategy to increase antileukemia activity of heat shock protein 90 inhibitor 17-allylamino-demethoxy geldanamycin. Cancer Res 2005;65:10536-44.

[9] Bali P, Pranpat M, Bradner J, Balasis M, Fiskus W, Guo F, et al. Inhibition of histone deacetylase 6 acetylates and disrupts the chaperone function of heat shock protein 90: a novel basis for antileukemia activity of histone deacetylase inhibitors. J Biol Chem 2005;280:26729-34.

[10] Radujkovic A, Schad M, Topaly J, Veldwijk MR, Laufs S, Schultheis BS, et al Synergistic activity of imatinib and 17-AAG in imatinib-resistant CML cells overexpressing BCR-ABL-inhibition of P-glycoprotein function by 17-AAG. Leukemia 2005;19:1198-206.

[11] Peng C, Li D, Li S. Heat shock protein 90: a potential therapeutic target in leukemic progenitor and stem cells harboring mutant BCR-ABL resistant to kinase inhibitors. Cell Cycle 2007;6:2227-31 
[12] Santini V, Gozzini A, Ferrari G. Histone deacetylase inhibitors: molecular and biological activity as a premise to clinical application. Curr Drug Metab 2007;8:383-93.

[13] Lane AA, Chabner BA. Histone deacetylase inhibitors in cancer therapy. J Clin Oncol 2009;27:5459-68.

[14] Fiskus W, Pranpat M, Balasis M, Bali P, Estrella V, Kumaraswamy S, et al. Cotreatment with vorinostat (suberoylanilide hydroxamic acid) enhances activity of dasatinib (BMS-354825) against imatinib mesylate-sensitive or imatinib mesylate-resistant chronic myelogenous leukemia cells. Clin Cancer Res 2006;12:5869-78.

[15] Xu Y, Voelter-Mahlknecht S, Mahlknecht U. The histone deacetylase inhibitor suberoylanilide hydroxamic acid down-regulates expression levels of Bcr-abl, c-Myc and HDAC3 in chronic myeloid leukemia cell lines. Int J Mol Med 2005;15:169-72.

[16] Ferrari G, Pastorelli R, Buchi F, Spinelli E, Gozzini A, Bosi A, et al. Comparative proteomic analysis of chronic myelogenous leukemia cells: inside the mechanism of imatinib resistance. J Proteome Res 2007;6:367-75.

[17] Kircher B, Schumacher P, Petzer A, Hoflehner E, Haun M, Wolf AM, et al. Antileukemic activity of valproic acid and imatinib mesylate on human Ph+ ALL and CML cells in vitro. Eur J Haematol 2009;83:48-56.

[18] Morotti A, Cilloni D, Messa F, Arruga F, Defilippi I, Carturan S, et al. Valproate enhances imatinib-induced growth arrest and apoptosis in chronic myeloid leukemia cells. Cancer 2006;106:1188-96.

[19] Navakauskiene R, Treigyte G, Gineitis A, Magnusson KE. Identification of apoptotic tyrosine-phosphorylated proteins after etoposide or retinoic acid treatment. Proteomics 2004;4:1029-41.

[20] Gambacorti-Passerini C, le Coutre P, Mologni L, Fanelli M, Bertazzoli C, Marchesi E, et al. Inhibition of the ABL kinase activity blocks the proliferation of BCR/ABL+ leukemic cells and induces apoptosis. Blood Cells Mol Dis 1997;23: 380-94.

[21] Seigneurin D, Champelovier P, Mouchiroud G, Berthier R, Leroux D, Prenant $\mathrm{M}$, et al. Human chronic myeloid leukemic cell line with positive Philadelphia chromosome exhibits megakaryocytic and erythroid characteristics. Exp Hematol 1987; 15:822-32.

[22] Beran M, Pisa P, O'Brien S, Kurzrock R, Siciliano M, Cork A, et al. Biological properties and growth in SCID mice of a new myelogenous leukemia cell line (KBM-5) derived from chronic myelogenous leukemia cells in the blastic phase. Cancer Res 1993;53:3603-10.

[23] Mahon FX, Deininger MW, Schultheis B, Chabrol J, Reiffers J, Goldman JM, et al. Selection and characterization of BCR-ABL positive cell lines with differential sensitivity to the tyrosine kinase inhibitor STI571: diverse mechanisms of resistance. Blood 2000;96:1070-9.

[24] Ricci C, Scappini B, Divoky V, Gatto S, Onida F, Verstovsek S, et al. Mutation in the ATP-binding pocket of the ABL kinase domain in an STI571-resistant BCR/ABL-positive cell line. Cancer Res 2002;62:5995-8.

[25] Bug G, Gul H, Schwarz K, Pfeifer H, Kampfmann M, Zheng X, et al. Valproic acid stimulates proliferation and self-renewal of hematopoietic stem cells. Cancer Res 2005;65:2537-41.

[26] Molloy MP, Phadke ND, Maddock JR, Andrews PC. Two-dimensional electrophoresis and peptide mass fingerprinting of bacterial outer membrane proteins. Electrophoresis 2001;22:1686-96.

[27] Huang D, Liu X, Plymate SR, Idowu M, Grimes M, Best AM, et al. Proteomic identification of 14-3-3 sigma as a common component of the androgen receptor and the epidermal growth factor receptor signaling pathways of the human prostate epithelial cell line M12. Oncogene 2004;23: 6881-9.
[28] Tipping AJ, Mahon FX, Lagarde V, Goldman JM, Melo JV. Restoration of sensitivity to STI571 in STI571-resistant chronic myeloid leukemia cells. Blood 2001;98:3864-7.

[29] Steinberg M. Dasatinib: a tyrosine kinase inhibitor for the treatment of chronic myelogenous leukemia and philadelphia chromosome-positive acute lymphoblastic leukemia. Clin Ther 2007;29:2289-308.

[30] Jabbour E, Cortes J, O’Brien S, Giles F, Kantarjian H. New targeted therapies for chronic myelogenous leukemia: opportunities to overcome imatinib resistance. Semin Hematol 2007;44:S25-31.

[31] Gambacorti-Passerini C, Dong-Wook Kim, Kantarjian H, Brummendorf TH, Dyagil I, Griskevicius L, et al. An ongoing phase 3 study of bosutinib (SKI606) versus imatinib in patients with newly diagnosed chronic phase chronic myeloid leukemia. Blood (ASH Annual Meeting Abstracts) 2010;116:208.

[32] Hantschel O, Wiesner S, Guttler T, Mackereth CD, Rix LL, Mikes Z, et al. Structural basis for the cytoskeletal association of Bcr-Abl/c-Abl. Mol Cell 2005;19:461-73.

[33] Wolanin K, Magalska A, Kusio-Kobialka M, Podszywalow-Bartnicka P, Vejda S, McKenna SL, et al. Expression of oncogenic kinase Bcr-Abl impairs mitotic checkpoint and promotes aberrant divisions and resistance to microtubuletargeting agents. Mol Cancer Ther 2010;9:1328-38.

[34] Gleixner KV, Ferenc V, Peter B, Gruze A, Meyer RA, Hadzijusufovic E, et al. Polo-like kinase 1 (Plk1) as a novel drug target in chronic myeloid leukemia: overriding imatinib resistance with the Plk1 inhibitor BI 2536. Cancer Res 2010;70:1513-23.

[35] Fontana S, Alessandro R, Barranca M, Giordano M, Corrado C, Zanella-Cleon I, et al. Comparative proteome profiling and functional analysis of chronic myelogenous leukemia cell lines. J Proteome Res 2007;6:4330-42.

[36] Pizzatti L, Sa LA, de Souza JM, Bisch PM, Abdelhay E. Altered protein profile in chronic myeloid leukemia chronic phase identified by a comparative proteomic study. Biochim Biophys Acta 2006;1764:929-42.

[37] Grebenova D, Kuzelova K, Pluskalova M, Peslova G, Halada P, Hrkal Z. The proteomic study of sodium butyrate antiproliferative/cytodifferentiation effects on K562 cells. Blood Cells Mol Dis 2006;37:210-7.

[38] Gatto S, Scappini B, Pham L, Onida F, Milella M, Ball G, et al. The proteasome inhibitor PS-341 inhibits growth and induces apoptosis in Bcr/Ablpositive cell lines sensitive and resistant to imatinib mesylate. Haematologica 2003;88:853-63.

[39] Baccarani M, Martinelli G, Rosti G, Trabacchi E, Testoni N, Bassi S, et al. Imatinib and pegylated human recombinant interferon-alpha2b in early chronic-phase chronic myeloid leukemia. Blood 2004;104:4245-51.

[40] Fiskus W, Pranpat M, Bali P, Balasis M, Kumaraswamy S, Boyapalle S, et al. Combined effects of novel tyrosine kinase inhibitor AMN107 and histone deacetylase inhibitor LBH589 against Bcr-Abl-expressing human leukemia cells. Blood 2006;108:645-52.

[41] Lee SM, Bae JH, Kim MJ, Lee HS, Lee MK, Chung BS, et al. Bcr-Ablindependent imatinib-resistant $\mathrm{K} 562$ cells show aberrant protein acetylation and increased sensitivity to histone deacetylase inhibitors. J Pharmacol Exp Ther 2007;322:1084-92.

[42] Kim JH, Hahm B, Kim YK, Choi M, Jang SK. Protein-protein interaction among hnRNPs shuttling between nucleus and cytoplasm. J Mol Biol 2000;298:395-405.

[43] Iervolino A, Santilli G, Trotta R, Guerzoni C, Cesi V, Bergamaschi A, et al. hnRNP A1 nucleocytoplasmic shuttling activity is required for normal myelopoiesis and BCR/ABL leukemogenesis. Mol Cell Biol 2002;22:2255-66.

[44] Notari M, Neviani P, Santhanam R, Blaser BW, Chang JS, Galietta A, et al. A MAPK/HNRPK pathway controls BCR/ABL oncogenic potential by regulating MYC mRNA translation. Blood 2006;107:2507-16. 